\title{
The Communication Language of the Concept of Fellow-Townsmenship in Turks in Social Media
}

\author{
Türklerde Hemşehrilik Kavramının Sosyal Medyadaki İletişim Dili
}

\section{Şebnem GÜRSOY ULUSOY * Özge GÜRSOY ATAR**}

\begin{abstract}
Within the scope of the concept of the power of social media to create social movements, the frequency of citizens' communication with each other on social media was examined. Especially those who migrate from rural areas to cities have limited restrictions on maintaining their relations with the citizens. However, this group can reach its citizens through social media and follow the current events of their country. Thanks to social media, fellow citizens who never know each other find and communicate with each other. In this sense, social media has become the field of continuing the meeting culture and traditions of people with common culture and common traditions.
\end{abstract}

Keywords: Fellow-Townsmenship, Communication Language, Social Media, Social Movement, Migration, Communication

$\ddot{O}_{z}:$ Sosyal medyanın toplumsal hareket yaratma gücü kavramı kapsamında hemşehrilerin sosyal medyadan birbirleriyle iletişim kurma sıklıkları incelenmiştir. Özellikle kırsal kesimden kentlere göç eden kesim hemşehrilik ilişkilerini devam ettirmek konusunda kısıtlılık yaşamaktadır. Ancak bu grup sosyal medya üzerinden hemşehrilerine ulaşabilmekte ve memleketlerine ait güncel olayları takip edebilmektedir. Sosyal medya sayesinde birbirini hiç tanımayan hemşehriler birbirlerini bulmaya ve iletişim kurmaktadırlar. Bu anlamda sosyal medya ortak kültür ve ortak geleneklere sahip kişilerin buluşma kültür ve geleneklerini devam ettirme alanı haline gelmiştir.

Anahtar sözcükler: Hemşehrilik, İletişim Dili, Sosyal Medya, Toplumsal Hareket, Göç, İletişim

Within the scope of research, the communication processes of the people from Bolu and Şarköy, who live in the big cities of Turkey, in social media were examined through Bolu and Şarköy's official social media accounts. In this context, the official social media accounts of those cities and the shares of the members of these accounts were examined through Facebook and the last one-year history of the common discourses in their shares was examined through the shares with content analysis. The second step of the research was to reach 10 participants through social media accounts and to ask about the progress of the fellow-townsmen relations of social media and the level of awareness that social media creates in their communication levels with their fellow-townsmen. At the end of the study, both the findings determined from the social media accounts and the results of the survey were compared. In this sense, it has been examined

\footnotetext{
* Dr. Öğr. Ü., İstanbul Gelişim Üniversitesi, Uygulamalı Bilimler Yüksekokulu, Medya ve İletişim Sistemleri, İstanbul.sgursoy@gelisim.edu.tr, https://orcid.org/0000-0003-3288-6857

** Dr. Öğr. Ü., Beykent Üniversitesi, Güzel Sanatlar Fakültesi, İstanbul. ozgeatar@beykent.edu.tr, https://orcid.org/0000-0003-4376-269X
} 
whether social media has the power to create a social movement in the concept of fellowtownsmenship.

\section{The Concept of Fellow-Townsmenship, Fellow Townsmen Associations and the Concept of Migration}

Industrialization of Turkey since 1950 and the resulting rural migration have revealed the fact that people have started to leave their towns and cities and have started to live in urban areas. One of the most important returns of industrialization is the replacement of manpower with the use of machinery for industrial power. The need for manpower is reduced when manpower is replaced by machinery in rural areas. "Thus, development of poverty as an important fact with its associated subjects advanced together with the matters in the process of urbanization caused by a rapid migration" (Romano \& Penbecioğlu 2009, 136). One of the basic facts that emerge with migration is the concept of poverty and people living in the slums. In the West, the concept of squatting and being the residents of slums emerged in the $19^{\text {th }}$ century. In Turkey, the formation process of slums started around the year 1945 as a result of the process of urbanization and the increased internal migration in connection therewith (Mirza 2016, 21). The concept of the slum, which has emerged as a result of the settlement process of poor people from rural areas to big cities, refers to the neighborhoods that are usually established near factories. The concept of poverty culture identifies the common conditions in the lifestyles of poor peasants and poor workers in large urban areas. In this case, the people living in this culture are in a group that does not integrate with national institutions and is struggling to maintain their lives in a low-level social structure. (Mirza 2016, 22) People looking after each other's fellow townsmen in this culture of poverty has emerged as an urbanite-peasant ideology. Within the concept that has been expressed as poverty culture, looking after each other's fellow townsmen has been formed also in the sense of looking after one's own past. In this sense, the period during which the concept of fellow-townsmenship and fellow townsmen associations have become functional and have increased in Turkey is the same as the rural to urban migration period. Migration is the movement of individuals or masses in a residential area from a certain group or piece of land, to another piece of land (Dural 2007, 22). This mass movement generally refers to a process that starts individually and then leads people to take their relatives and friends with their fellow-townsmenship approach. Economic and social developments also play a role in the growth tendencies of cities (Kaçer 2017, 36). Industrialization and increasing population are influential in urban growth. Population growth leads to increased needs. Urban growth consists of processes that involve many different morphological structures in urban growth (Millward 2011, 53-54). The basis of the concept of migration is the desire to reach a better social life. "The phenomenon of migration has continued to be important in every section of human history, in parallel to the increasing search for the better" (Güngör 2006, 229). It is observed that immigrants facilitate the process in which they encourage and assist the migration of also their family members and friends, and that the fact that immigrants (sometimes all the individuals living in a single region) migrate to a single place is the result of this solidarity of fellow-townsmenship (Öksüz 2018, 88).

There is a great connection between the migration process and the relationships of fellowtownsmenship. The immigrant draws relatives and kins to the same city or even to the region. Or the immigrant becomes the greatest supporter of others in the process of settling and establishing a new life. Groups and small groups that are marginalized especially in urban areas, set up some associations in order to adapt to the new environment, to protect their culture and to maintain their own existence. These associations are mostly established through "fellowtownsmenship". For example, the group of people who migrated from the district of 'Of' in Trabzon to Trabzon city center establish the "Association of the People of Of" and the ones who 
migrated from Trabzon to Ankara can establish the "Association of the People of Trabzon" in Ankara (Öksüz 2018, 88-89). When the phenomenon of fellow-townsmenship is examined, it is seen that these people generally consist of the migrating part of the society and they attach importance to the concept of fellow-townsmenship in their lives as a social fact. The notion fellow-townsmenship is a concept of social and organizational importance, but sufficient research has not been conducted on the field. While the concept of 'fellow-townsmenship' is basically a spatial approach, it symbolizes a secondary space created by the people who are drifted away from the space (Kurtoğlu 2018). The migrant population is observed to be generally located close to each other within the framework of community and fellowship relations. Among the features of urbanization in Turkey, it is seen that the migrants from villages, districts, provinces and generally the same geographical region are gathered in the same neighborhoods and even in the same streets of the cities (Altay \& Gümüş 2010, 232). Alienation constitutes the most important point in the processes of both civilizations. People are more in need of fellow-townsmenship closeness because they are unfamiliar with themselves and their environment (Öksüz \& Öztürk 2017, 1182). After the 1950s, with the industrialization, the phenomenon of migration has become more prevalent and the concept of fellowtownsmenship has gained more importance. With the replacement of manpower in the villages, the need for people decreased and a certain group began to migrate from the village to the city. The groups that did not want to lose their own identity during this migration process started to establish associations among themselves. As a result of this process, associations are established in cities generally named in the sense of local solidarity associations. These associations aim to establish solidarity among the people of the city, to provide cooperation, to develop the image of fellow-townsmenship, on the other hand, to ensure the continuation of their customs and traditions and to transfer this consciousness to the future generations (Terzi \& Koçak 2014, 138).

The facts, which fellow-townsmen look after and protect each other and maintain the common customs and traditions of the region they come from, are seen as a process that emerges as a result of this process. The fellow townsmen people help each other when they start a job. The person who is the owner of the workplace or the person responsible for the job can give priority to the fellow townsmen in the recruitment process. After the 1960s, new policies in the field of tourism began to be determined. Ecological and economic policies have been implemented (Akoğlan Kozak \& Kizllırmak 2006, 5). The main reason for these practices is based on industrialization and migration from rural to urban areas. The main reason for the increase and diversification of industrial products is that people living in rural areas have started to work in factories in cities.

\section{Social Media and the Power of Interpersonal Communication}

In the Article 76 of the Municipal Law No. 5393, the functions of the city council have been described as "the development of urban vision and fellow-townsmenship consciousness", "protection of the rights and law of the city" and "sustainable development, environmental awareness, social cooperation and solidarity, transparency and accountability" and thus, in a sense, the fact that fellow townsmen protect and help each other officially emerged. Granovetter (1973), with the conceptualization of 'The Strength of Weak Ties', points to the importance of newly established friend relationships in finding a new job for a job-changing person. Years later, a study conducted in the 1990s (Montgomery 1991) reveals that the rate of employment using the information obtained through friends and relatives is still very high even in Western societies (Beyhan 2011, 207). For all these friend relationships and relative relationships, being a fellow townsman seems to have a similar advantage. It is seen that people help people whom they see close or from the same group. People want to get away from the feeling of loneliness 
and being on their own by becoming members of similar groups. Fellow-townsmenship associations are defined as "actualizing the principles of rural loneliness, accountability, participation and decentralization principles in large cities" (Akdemir 2017, 295). With the municipal law, municipalities have officially taken on the task of spreading fellowtownsmenship consciousness. The picture of this communication process is simply the hope of a person holding on to life. People from the same region are also observed to have a common dialect and language such as Laz Turkish, Anatolian Turkish etc. This is actually seen in regional language characteristics. In his work 'Archeology of Knowledge', Foucault (2011) makes it clear that when the production of thought is made through language, the free-thinking process cannot be possible because the language contains ideological discourses and the language will continue to be a means of pressure and power-building (Erkal \& Şentürk 2015, 343). In the consciousness of fellow-townsmenship, this process renews itself with the language that is formed with a common culture and common perceptions. In this context, the consciousness of fellow-townsmenship seems to increasingly continue with the industrialization process of the 1950s. In the 2000s, the concepts of social media and the Internet were introduced into this process. "Nowadays, media tools and products have been diversified but besides that, distinctions such as traditional media and new media have emerged. In this process, the structure and operation processes of the media sector have started to become complex" (Gürsoy Atar 2016, 351). Along with new communication technologies and developments, it has established new expression content and masses new experiences using audiences with new platforms causes to win (Sar1 2017, 71-72). New media technologies have created a social change.

The fact that the fellow-townsmenship associations started to be represented in social media coincided with the emergence of social media, which was mentioned as the new media. Fellowtownsmenship associations in social media have become a meeting place for fellow townsmen. The fact that social media facilitates and accelerates the communication processes of individuals and bring them together has constituted the basis of this process.

\section{Urban Culture and the Concept of Fellow-Townsmenship}

In his book The Condition of Postmodernity, David Harvey describes the modern city and mentions the people who are trapped between space and time. The jamming of time and space is, in fact, jamming that people living in cities, which keep changing with technology, experience. Because space and time cannot be independent of human, it is actually the people who are trapped or feel trapped. People living in modern cities are usually the ones who have migrated from rural areas. The people who are indicated as precariat or proletariat reside in the same neighborhoods as their fellow townsmen in cities (Harvey 2014; 2016). According to 2006 data, there are 8135 associations in Turkey (Aktaş 2012, 107). In this sense, fellowtownsmenship associations seem to represent a dense area in Turkey. Internal migration in Turkey began in the mid $20^{\text {th }}$ century and has become a continuity with the bonds and network of immigrants established in time, and the resulting condition seems to change the distribution of people living in the rural and urban areas of the country (Yakar \& Eteman 2017, 82). After the 1950s, the migration rate increased with the increasing population and advancing technology and the migratory masses started to establish and become a member of fellow-townsmenship associations in order not to feel lonely in the city, to get information about the place they live and to somewhat eliminate the longing for the region they came from. Fellow-townsmenship associations are seen as structured organizations of fellow-townsmenship social communication and relationship processes and networks (Aktaş 2006, 52-53). Fellow-townsmenship associations are an important place for connecting people of society, making them socialize and making 
them not to lose their essence. In addition to the official institutions, well-organized fellowtownsmenship associations are an integral part and representative of the social structure (Guida $2013,66)$. In fact, being a member of a group is also a part of feeling the confidence that one is a part of a large family and can ask for help when it comes to any bad situation.

The concept of fellow-townsmenship is also examined within the framework of the concept of organizational citizenship or organized citizenship (Potsakof 1990, 105). In his work Citizenship and Social Class published in 1950, Marshall stated that being intellectual, belonging to a particular group and feeling a part of a particular group are related to the communities and groups of which people are members (Marshall 1950). The concept of being a member of a social group has revealed itself with the consciousness of fellow-townsmenship in people who migrate from rural to urban areas. The concepts of citizenship and fellowtownsmenship are frequently seen in the concepts used to establish the concept of full membership in the society and to connect people to their country and place of residence. The need to be a member of a society or a region has made it necessary for people to be included in these concepts. In this way, they feel safer and happier (Holston 1196, 187). The concept of fellow-townsmenship and why people attach importance to the concept have always been subjects of research. Members of certain groups are observed to unionize and protect each other. Fellow-townsmenship is organized citizenship; it is the united masses.

The type of connection between justice and the sense of citizenship has been a subject of research. Justice judgments of those who attach importance to organizational citizenship have been investigated. Whether there are favoritism incidents among these people always represents a situation that is a subject of research. (Moorman 1991). In particular, favoritism seems to be more prevalent in the business environment. Business life is also a social phenomenon in people's lives (Organ 1997, 88-89). In this social environment, people often want to work with similar people with them, people come from their region or their fellow townsmen. Their business behaviors and organizational citizenship behaviors are similar (Moorman 1991, 845). There is a link between the social system and organizational citizenship behaviors (Smith 1983, 653). The evaluation of the concepts of business life and fellow townsmen protecting each other, which are mentioned as organizational citizenship, reveals that the fellow townsmen who live in the social system find and protect each other. The understanding of freedom and equality, which represents modern democracy, states that in a pluralist democracy, this will not be fully actualized. The grouping of people as citizens increases the sense of confidence that people feel for themselves and each other (Mouffe 1992). The behaviors of citizens can vary depending on the region they come from and their relationships with the people in this region (Bateman 1983, 589). In many cases, citizenship and fellow-townsmenship are considered together. There is a great connection between the concepts of citizenship and fellow-townsmenship and the concept of social change. In English, the word citizenship is also used in the sense of fellowtownsmenship (Kanovsky 1994, 658).

\section{The Concept of Citizenship and Its Representations in Social Media}

International communication and international technology are changing very rapidly (Blanchard $2011,104)$. In the last decade, there has been a transformation in the world that confirms Marshall McLuhan's concept of the global village. The basis of this transformation is that people like to follow information and developments about each other. Even people who have not been in contact for many years receive news about each other through social media and have access to detailed information about each other. People enjoy following what other people do and how they do it. Social media makes this very easy (Israel 2009).

"Now, traditional manners, attitudes, politics or culture no longer put up resistance against 
technology, but technology changes people, cultures, countries and policies at a considerable extent" (Iş1 2019, 178). Social media has become a global network that flows out of space and time and allows people to constantly hear from each other. Social media and blogs also do storytelling. People follow stories and events from social media and blogs apart from the mainstream media (Hewitt 2005). In this sense, it can be seen that the people who are the fellow townsmen have the same goals as mentioned above in their aim to follow each other from social media. As anyone who tried introducing new technologies to an organization knows, tools and tactics are easy. Getting people to believe and adopt is hard. It requires organizations to change their culture, and where there is change, there will almost always be resistance (Shih, 2011). Cultures have created an area of existence, which in the past tended to differ from each other. Although it has been almost 60 years since Marshall McLuhan put forward the idea that the world would become a global village with technology in the 1960s, it is seen that what he says has become gradually real thanks to social media. Together with the changes in the Internet and recent technology, cultures and nations have become more connected to each other, although they retain some of their original elements (Bekiroğlu \& Balc1 2016, 431).

As a social being, the human being carries this social structure to the area where he/she goes and lives. People share their geographical location as part of the algorithm layout (Jiang \& Wang 2018, 18-20). Being social means being part of or a member of a community. Social communities have social benefits (Mossberger \& Tollbert 2008, 47). While explaining the concept of social community, it is necessary to mention the concepts of public space and private space. Social media creates both a public space and constitutes a private space. "The distinction between the public space and the private space is a contradiction discussed by social scientists for centuries. The fact that the public space is attributed to men and the private space is attributed to women has led to the reinforcement of the distinction between men and women in the social order" (Özdemir 2018, 143). Everyone has a private space in social life. Migrants also have a private space established among themselves. It is a known fact that every problem in social life is related to other social events (Arslan 2007, 86). The relationship between community and congregation should be considered as a private space as well. "In short, the country where there has been immigration is imaginary geography and the fellow townsman is the member of the imaginary community coming from that imaginary area" (Kurtoğlu 2018). Fellow townsmen represent the people who feel as members of a particular group and as loyal to that group. Fellow-townsmenship is a social bond and belonging (Kurtoğlu 2001). People exist and continue their existence in social groups and these social groups are basically linked to the region they live in. In this sense, being fellow townsmen from the same city or region gains importance. Fellow townsmen immigrants try not to break their cultural and social ties with each other with the associations they establish. The people who keep this social bond alive feel themselves in the land where they come from. This prevents them from experiencing social loneliness and satisfies their wish to be part of a group. In conceptual terms, the word "fellow townsman" refers to a situational relationship between fellow townsmen. When this situation is defined, fellow-townsmenship is a phenomenon that shows one of the two people whose common aims are structured in the same geographical area relative to the other. With its second meaning, fellow-townsmenship defines the interrelationships between people whose hometowns are in the same geographical location or who feel that they belong in the same geographical region and also the relationships, social ties, and identities arising from these ties (Kurtoğlu 2018).

In this sense, social media is seen as a link that connects people socially. Campaigns through social media are frequently used to reach masses (Carlson \& Djupsund 2014, 24-24). The two most important links between people are the community and congregation relations. In 
this sense, having lived in the same territory or having common relatives and friends emerges as a situation that makes it easier for people to connect with their roots and backgrounds. For the individuals who drift apart from their traditional ties, who struggle to exist in a foreign place and who are in search of belonging, 'coming from the same place' is of great importance. In order for the new inhabitants of the city to adapt to their new lives, the fellow-townsmenship associations, which are an example of community ties, undertake major functions" (Köse 2008, 221). From a community point of view, the social media system is observed to make a certain group the members of a community in the direction of common goals and expectations. Shares of the same style, similar words, similar discourses, and expressions standardize people and transform them into similar people and the members of similar associations. The concept of fellow-townsmenship is seen to be closely intertwined with the concept of favoritism in social structure (Kurtoğlu 2012, 141-142). The institutional spaces of the immigrants who want to make them selves visible in the city have been associations. Associations inform people about other people whom they do not know and provide that people help each other about public institutions, hospitals and schools (Fliche 2005; Hersant \& Tourmarkine 2005). It is possible to indicate that the proximity of fellow townsmen is a state that continues among occupational groups as well. It is also possible to state that the fellow-townsmenship approach and the trust and closeness that fellow townsmen feel for each other is also seen among the teachers (Güven \& Demir 2014, 3210-3212). Being part of a group is always important in human life. The easiest group to become members of the rural people coming to the city are the fellowtownsmenship associations and groups. Social media makes this process much easier. In the concept of urban culture, social media both creates the notion of fellow-townsmenship and plays a role in the promotion of the city. The content shared on social media can spread rapidly in traditional media and the topics, texts and pictures that appear in traditional media can spread rapidly in social media. The sharing and discourse speed of social media and the number of people it reaches are much higher (İzmirli Olmak Symposium Book 2009, 229-230). In general, what underlies social media to spread very fast is that social media is easy to use and that it can be easily accessed on smartphones. As the new media is changing and becoming increasingly widespread, mass media have gone through a massive process of transformation and improvement (Yağız et al. 1). Social movements and social organization are everywhere with people. The basis of social media is the gathering of groups of people and of people who know each other from a particular group. Social movements reveal their strength and emergence processes by how much they are supported by society. Generally, this support is provided by the fluent relations established with the media (K1lıç 2009, 151).

The concept of social networking is often conceptualized under social capital theory. Although the literature on social capital is different from the social network literature, it is largely convergent. For this reason, it may be useful to briefly define social capital before the concept of social networking. Putnam (2000) describes social capital as "social organization features such as networks, norms, and trust that facilitate coordination and cooperation for mutual benefit", while Bourdeieu (1986) stated it as "the sum of potential resources in durable or permanent social networks" and Woolcock (1998) interpreted social networks as "the mutual exchange of knowledge, trust, and norms" (Akgiş \& Karakaş 2018, 22-23). The concepts of social network and social capital are seen as close concepts. Although social capital and social network concepts are seen in a different understanding and literature, they stand close to each other. Putnram indicated social networks as common networks and social organization structures that seek mutual benefit and provide cooperation (Akgiş \& Karakaş 2018, 22-23).

Bourdieu gave a different perspective on the topic and indicated it as the total of resources with potential in social networks (Bourdieu 1986). Although social media is used for different 
purposes, it also continues its existence as a medium where people can share pictures, poems, videos and writings which are part of their origins and the lands that they feel belong in, regardless of time and place. In this sense, it is seen as a field where the sense of fellowtownsmenship is formed and kept alive. Since social media provides ease of communication, it is seen as a field where communities are easily formed and gathered. People can share and talk about topics of interest such as political speeches, common photo tastes, and television programs. Individuals who do not know each other can define themselves as 'us' within the context of the fellow townsmen concept. The ties between people who have the feeling of belonging to the same geographical location sometimes affect their personal identity. The number of social networks gathered around the notion of fellow-townsmenship in social media is observed to have exceeded thousands.

Our daily life consists of a trust relationship built on institutional and social relations. Social capital is an important concept. It represents the trust in friendship relationships that people establish with each other. In general, the emphasis of social capital is in social relations (Topçuoğlu \& Eroğlu 2013, 128). On the one hand, economic relations in urban environments have developed the processes of fellow-townsmenship, which function as an important institution in the process of urbanization, and on the other hand, they have created some forms of private life in this social-economic and social-cultural environment. Fellow-townsmenship relations (traditional, based on solidarity, community relations) have not only provided the people, who migrated from the village, to settle in the city and created their prior knowledge, but also prevented the disappearance of people in the city and re-established their traditional solidarity patterns by moving them into the urban environment. For example, people from the provinces of Sivas, Erzurum, Kars, Trabzon, and Kastamonu settled in neighborhoods and districts in the cities. They built their own houses and workplaces, they established their fellowtownsmenship associations and they carried out their relations in this way (Autonomous \& Kahya 2008, 18).

All these relationship processes reveal that these relations are formalized with associations and the members of the associations protect and favor each other. Fellow-townsmenship associations are an area where different groups of the society can be represented together and where people come together to find solutions to the problems of the city and people (Usta \& Bilgi 2017, 225). In addition, the masses, who were detached from the countryside as a result of the migration from the countryside, and who were gathered in the cities, were not able to adapt to the urban life and could not adopt the urban values and as a result, they are stuck between rural life and urban life and they remain strangers to urban life. This process is observed to be related to fellow-townsmenship relations (Aktas et al. 2006, 53). The family and the people who complete the family are observed to have many social relations and strong ties including kinship and neighborhood. For example, friendship, citizenship, and membership in communities represent the other ties that the individual and family are in (Özbay 2014, 2).

\section{Research}

Within the scope of the research, the social media accounts of the fellow-townsmenship associations of Mengen district of the province of Bolu in the Anatolia region in Turkey and the fellow-townsmenship associations of the Şarköy district of the province of Tekirdag in Thrace, Western Turkey were examined. Facebook was preferred as social media. In the last one year in the social media accounts of the people from two different districts in two different regions, the communication language that people established with each other was examined through the concept of fellow-townsmenship. Afterward, in-depth interviews with 5 members of each group were conducted and the concept of fellow-townsmenship and the phenomenon of social media 
were examined. On Facebook, Bolu Mengen has a total of 3 groups. Mengen-Bolu, Mengen Gündem, Mengen-Bolu-Turkey were identified as three pages. Among these pages, the group with the highest number of members was selected and analyzed. 6,709 people seem to follow the Mengen Gündem page. Only the shares that were commented on the social media page were analyzed. The shares between 1 January 2018 and 31 December 2018 were reviewed. Since the official page of Mengen Association is not used actively and no one had commented on the shares made, the Mengen Gündem page, which is the most preferred page with the highest number of followers, was examined instead of the association page. The number of people who follow the Mengen Gündem page is higher and the sharing of news is more frequent. The Google search for Şarköy revealed 5 official accounts. In the same way, the most followed page among these pages was chosen. Şarköy'ün Sesi page is followed by 14,722 people. The last one year shares of Şarköy'ün Sesi page were also examined. A common conclusion was drawn from the results of in-depth interviews with all the shares and individuals, and how the concept of fellow-townsmenship was seen in two regions and how the concept of fellow-townsmenship progressed and represented in social media were examined. The two social media pages, which can be seen as social media newspapers, were preferred in the research.

Finally, the two districts were comparatively examined in terms of whether there is a difference between the points of view to the concept of fellow-townsmenship through social media representations in Anatolia and Thrace regions of Turkey.

\section{Part 1 - Research on the Social Media Pages}

\section{Mengen Gündem Facebook Page Review}

1. Share - 2 January 2018. A reconditioning report on the Mengen district state hospital was criticized by those who were from Mengen. However, no one has responded to anyone's comment. On the other hand, the discourse style of the three people who make comments is observed to be common.

2. Share - 6 January 2018. In general, 5 people commented about the appointment of two doctors to the Mengen region and two people shared the news. It is seen that the comments are only personal comments and nobody responds. One person made the statement "all the best for our city".

3. Sharing - 14 January 2018. The only comment is about the Mengen Cookery Festival news. This comment was made by a stranger to participate in the festival and 11 people shared this news on their pages.

4. Sharing - 17 February 2018. It is the news about the pose of the District National Education Director with the gun. Three people commented on the incident, one did not give consent to the incident and another person commented that he/she did not agree on the first person who made a comment and stated: "we are all from the Black Sea region". Another person commented that he/she did not find it appropriate 'to pose with a gun due to his position'.

5. Sharing - February 17, 2018. It is a death announcement. 4 people offered their condolence.

6. Sharing - March 4, 2018. It is the closing news of a faculty in Mengen. 4 people commented that the Mengen logo in the news was small.

7. Sharing - May 1, 2018. It is a death announcement. 2 people offered their condolence.

8. Share - May 4, 2018. It is news about a school opened in Mengen. 4 people commented and indicated their best wishes.

9. Share - May 15, 2018. It is a religious sharing for the first night of Ramadan. 21 people shared it on their pages.

10. Share - June 30, 2018. A visual of Mengen was shared. 3 people have left a comment. They 
expressed their reaction to the growth of Mengen.

11. Sharing - July 19, 2018. It is the news about Mengen $33^{\text {rd }}$ Cookery festival. 4 people commented and said they did not like the festival logo. 47 people posted it on their pages.

12. Sharing - July 20, 2018. It is a video about the beauties of Bolu. 49 people shared it on their page.

13. Sharing - 21 July 2018. It is the news that Mengen Mufti's office has moved to its new building. 1 person wished his/her best wishes.

14. Sharing - August 14, 2018. It is about the news that people, who change their US dollars and buy Turkish Liras, in Mengen get fruit and vegetables for free. It is the news with the topic "change your dollars and look after your country". Only one comment can be seen. 3 comments were determined to be blocked. 39 people posted the news on their page.

15. Sharing - August 30, 2018. It is news about a request for building a road in the Yedigöller (seven lakes) region. 6 people commented on this news and stated that the new roads have distorted Mengen's nature. 22 people shared it on their pages.

\section{Şarköy59 Facebook Page Review}

Şarköy59 Facebook page was determined as the most followed Şarköy social media page. So the review was made through this page. Since Şarköy is a coastal town, the shares were observed to be much more intense. Therefore, much more posts were reached by the researcher as compared to Bolu-Mengen page. The posts were observed to be much more intense than the Mengen case. Only the posts that were commented about fellow-townsmenship were evaluated.

1. Share - January 1, 2018. No comments were made.

2. Sharing - 7 January 2018. A current picture of Şarköy was shared. One person shared the song 'Şarköy, my heaven'.

3. Sharing - January 9, 2018. It is a sharing from the summer period. Two people shared the wish of 'a good day for the beautiful people of Şarköy'.

4. Sharing - 20 January 2018. 5 fellow townsmen made comments about many problems in natural gas and electricity under a picture. These people were observed to live in Şarköy in the winter as well.

5. Sharing - February 4, 2018. A picture was shared from the Şarköy harbor. One person expressed his/her longing for Şarköy. Another person asked a friend if he/she remembered the place in the picture.

6. Sharing - February 16, 2018. A picture was shared about the urbanization of Şarköy and the construction of large buildings. One person wrote a sentence emphasizing that Şarköy would be damaged by urbanization.

7. Sharing - March 8, 2018. The coastal area was flooded after rain. A picture of this was shared. 18 people commented. In general, everyone expressed their longing for the summer and their love for Şarköy. It was observed that people frequently wrote and responded to each other's comments.

8. Sharing - April 7, 2018. The place, which is also called as Şarköy pier, harbor and wave breaker, was shared. 19 people wrote comments. They expressed their aspirations to Şarköy in general. People were observed to comment on and like each other's comments.

9. Sharing - April 23, 2018. The video of 23 April Children's Day celebrations was shared. 19 people commented and congratulated the organization. Some people from Şarköy were observed to come from nearby regions only for the organization.

10. Sharing - May 8, 2018. It is a sharing that tells us that spring is coming in Şarköy. 13 people wrote a comment. 35 people shared the pictures in their profile. 357 people liked the pictures. In 
general, the people who made comments were observed to spend the summer in Şarköy. They shared expressions like "we will soon be there". It was seen that there is a mass who admires Şarköy.

11. Sharing - May 18, 2018. It is a sharing about the infrastructure works of the municipality. The comments were written by the people who stated that they spent the summers in Şarköy. People indicated that the municipality was insufficient in terms of infrastructure.

12. Sharing - May 27, 2018. The final state of Şarköy was broadcasted live. 111 people commented. 324 likes were observed in 44 sharing. It was seen that people answered each other even if they did not know each other well and asked if the old places remain or not.

13. Sharing - June 6, 2018. The picture of rain was shared from Şarköy. 43 people commented. Şarköy writings of love and longing attracted attention. 5 people were observed to say 'I will be there soon'.

14. Sharing - June 23, 2018. It is a live wedding sharing. During the day, it was seen that young people went to the wedding by playing on the street. The couple parked their car and danced on the street and on the coast road. 43 people commented. In general, aspirations and wishes of happiness were written to Şarköy. People were observed to know each other remotely and comments like "the couple are the relatives of these people" were made.

15. Sharing - July 15, 2018. It is about the live broadcasts from Şarköy. One person wrote that Şarköy was very dirty in the summer.

16. Sharing - August 21, 2018. Eid celebration was held in Şarköy. Everybody wrote greetings. Fellow townsmen who were not in Şarköy were observed to also write holiday greetings.

17. Sharing - August 30, 2018. A current video was shared from Şarköy. 42 people left a comment. The comments reveal that people from Şarköy shared some of the missing issues of Şarköy. Fellow townsmen were seen to write to each other and commented on each other.

18. Sharing - September 20, 2018. It is the school fire news in Şarköy. 9 people commented. Everyone made comments like "God bless" or "sorry to hear what happened". 3 people posted the news on their pages.

19. Sharing - September 22, 2018. It is a summer beach picture from Şarköy. 1 people commented by using the word "beya" which is a local word in the Thrace region. People from Thrace, especially people from Şarköy and Tekirdağ were observed to add that word at the end of the sentence.

20. Sharing - October 1, 2018. It is a road video from Şarköy. 71 people left a comment. They stated that Şarköy was beautiful in all seasons. They stated that Şarköy was a very nice place but it had not been maintained enough. It was seen that the people who made these comments were generally from Şarköy.

21. Sharing - November 26, 2018. A winter scenery was shared from Şarköy. 2 people commented. In an interpretation, a person from Şarköy used the phrase "my sweet city". 2 people liked this comment.

22. Sharing - December 22, 2018. Snow scenery was shared from Şarköy. 7 comments were made and 7 people shared this picture on their pages. One person shared the song "my Şarköy, this dress suits you very well".

After the social media research, 5 in-depth interviews were conducted with 5 people from Bolu Mengen and 5 people from Tekirdağ Şarköy on the subjects of fellow-townsmenship and fellow-townsmenship in social media. These interviews are given below.

\section{The result of social media research}

\section{Mengen}


The use of social media accounts is observed to be preferred by the people who are mostly from Mengen but have migrated to metropolitan cities. It is seen that the people who write comments want Mengen to develop. Observations revealed that they are very careful about commenting on each other's comments and do not write unless they have to. The shares were made in three groups. These groups of shares were announcements on the cookery festivals of Mengen, announcements on deaths and current news and pictures from Mengen. On the Mengen Gündem (Agenda) page, which was examined as the social media account that was followed by the highest number of people, people are active about their shares. However, despite the high number of likes, people were observed to abstain about commenting. In this sense, it is not possible to indicate that a social media structure that supports the relations of fellowtownsmenship was created for Mengen.

\section{Şarköy}

As a result of the research carried out by Şarköy's social media account with the follow-up list with the highest number, Şarköy was observed to share posts regularly every day, the shared posts were intensely followed, regularly commented and people shared them on their personal pages. It was also seen that Şarköy, which is a seaside resort, is not only followed by people living there but also actively followed by people who spend the summer in Şarköy and return to big cities in winter. Especially the pictures shared about Şarköy every day and the common words "my beautiful Şarköy, my beautiful town" which people frequently write attract attention. Observations also exhibit that people make comments to each other, communicate actively through each other's acquaintances and carry the culture of fellow-townsmenship to social media.

\section{Part 2 of the Research \\ Interview questions}

1. Can you explain your region's approach to fellow-townsmenship?

2. Do you think that social media conduces to the meeting of fellow townsmen?

3. Do you think the communication processes established through social media are fluent and necessary?

\section{Bolu - Mengen}

\section{Years Old, Male, University Graduate, Municipal High Level Officer}

People from Mengen attach great importance to the concept of fellow-townsmenship; my family has been living in Mengen for 700 years and as a result of my family research, I have determined that we came here 700 years ago from the province of Corum. Since people from Mengen are especially cookery professionals, those who go out of their hometown find each other. I will answer your second question and your third question together. Social media is a quite new situation for us. However, I think it will be used more actively in the future even if it takes a long time.

\section{Years Old, Female, Retired Teacher}

My family is from Mengen, my father was a teacher and he wanted me to be a teacher. The culture of Mengen is very similar to the Turkish nomadic culture in Anatolia and therefore the kinship relations are very important. People are similar to each other here. Customs and traditions are very important to us. I do not agree to share and communicate on social media very much; we fellow townsmen can find each other also in big cities via acquaintances. I have lived in Ankara for 30 years. There, we can find our fellow townsmen through the association. However, my grandchildren live in Istanbul and they find their friends on Facebook; for 
example, they find their friends from primary school.

\section{0 years old, Male, Retired Inspector}

Even though I don't think that social media is necessary, this is a fact of the period we live in. Therefore, I think that social media should be used actively by fellow-townsmenship associations. I know that this isn't active right now in Mengen. I believe that the sharings in social media are very important for young people from Mengen, especially in order for the people who have migrated to big cities not to forget their culture.

Our sense of fellow-townsmenship can only go to our cousin's children, unfortunately. Very few people migrated from Mengen to big cities continue their connection with Mengen. Mostly village headmen have contact with the people originally from Mengen but living in metropolitan areas in order to support the villages. Fellow townsmen are gathered together in the Islamic memorial services that are organized every year.

\section{0 years old, Female, Banker}

Mengen is our city; every year, we participate in the Islamic memorial services in our village. All the people from Mengen come together in these Islamic memorial services. The people from Mengen who live in Istanbul, Ankara and even in Germany also come. Fellow townsmen meeting on holidays is celebrated in a festival mood. Fellow-townsmenship is very important in Mengen. People look after each other. I am actively following the Mengen Gündem (agenda) page on social media. Because I studied in Mengen for my primary school, I can find my friends from primary school. I even started my first job in a company where my father's friend from Mengen worked. Then he was very supportive to me.

\section{2 years old, Male, Teacher, Retired, Self-Employment}

My father came alone from Mengen when he was 12 years old. My father didn't have a lot of ties with Mengen but I have never broken my connection. My father had had six siblings. I even went and met his nephews and nieces that he didn't talk to. We have all kinds of people in our area. There are people who attach importance to the concept of fellow-townsmenship and there are who do not. I think that social media is very important for fellow-townsmenship. I believe that young people should actively follow their hometowns in social media, especially in terms of knowing their hometown, people from their hometown and keeping their culture alive.

\section{Tekirda}

\section{9 years old, Female, Retired Turkish Teacher}

Being from Şarköy has been a source of pride for me all my life. Summers and winters are beautiful in Şarköy, as well as its people. I am following everything about Şarköy and I am actively following facebook pages of Şarköy as well. As I follow the current events in Şarköy, I have the opportunity to find my fellow townsmen and talk to them. We have our Şarköy beautification association; we have a meeting every month. I will set up a social media account for this group as soon as possible.

\section{4 years old, Female, Housewife}

I spent my childhood and my youth in Şarköy; although I do not see many of my fellow townsmen, I go to Şarköy and it is great to find acquaintances and relatives. I think Facebook is very good because it has enabled people to hear from each other without going home. We usually go to Şarköy once a year but thanks to the Internet, we are communicating with all the acquaintances. And there are also the Şarköy pages; we follow the current events from them.

\section{8 years, Male, Artist}


I have been running a café beach with music in Şarköy for about 20 years. My parents are from Şarköy. I lived in Istanbul for a while then settled here. Kinship relationships of people are very strong here. Fellow townsmen here protect and favor each other but the most important thing is that the permanent inhabitants have the warmth of Thrace people. There is even such a group that neither their parents nor they are from Şarköy but they are like from Şarköy since they have lived here for a long time. These people feel that they are from Şarköy more than anyone else and they try to find solutions for people's troubles. I know so many of them. I think Facebook accounts are very important for people from Şarköy who do not live in Şarköy to communicate with each other.

\section{5 years old, Male, Municipal Official}

I have worked as a high-level municipal officer for a long time in Şarköy. I come from a family with a very long history in Şarköy. Being from Şarköy is something special. There are a lot of people here who are not from Şarköy but live here and feel that they are locals. I guess it is the case due to the fact that it is a coastal town. Şarköy has become a summer residence in the last 50 years. In the winter, only the locals stay in Şarköy and in the summer, it is unbelievably crowded. Social media also allowed Şarköy to develop and become a preferred summer resort. In the sense of fellow-townsmenship, I think that being Thracian is important to many people, if not to be from Şarköy. For example, people from Tekirdağ find each other and favor each other. 31 years old, Male, Company Employee

I was born and raised in Şarköy. When I went to Istanbul, I stayed with friends from Şarköy for 6 months. Fellow-townsmenship is very important in the culture of Thrace. For example, people from Şarköy and Tekirdağ use the word 'tebe ya' very much in the spoken language. I also manage a Şarköy fun page on social media. I am bringing people together. I organize tours to Şarköy. In this sense, I think social media is very important in the development of cities. My elderly relatives are using social media very actively to get news from their city. In this sense, I believe that social media has a very important role in fellow-townsmenship relations.

\section{The Result of One-to-One Interviews}

\section{Mengen}

As a result of the research, it was observed that the people who live in Mengen agree that Mengen should develop. It is seen that people who migrated to metropolitan cities and who do not live in Mengen continue their communications with the region. They seem to have a benevolent character to help and favor their fellow townsmen. They do not actively use social media. They seem to be hesitant about the use of social media. Observations revealed that people are divided into two in sharing information and news on social media. Youngsters think that social media is very important in general and also important for the development of the region.

\section{Şarköy}

Observations revealed that the common characteristic of all the people living in Şarköy or migrated to the big city is that they all have a great love for Şarköy. They stated that they could easily find their relatives via social media and manage their relations. Especially people who have been living in Şarköy for years but whose parents are not originally from Şarköy were observed to see themselves as people from Şarköy and actively participate in the fellowtownsmenship relations. People were seen to share current Şarköy pictures on their social media accounts with their fellow townsmen and relatives. People from Şarköy were observed to actively continue their fellow townsmen relationships through social media. 


\section{The Overall Result of the Research}

As a result of the social media research conducted in Mengen and Şarköy districts, it was observed that the Mengen region residents did not share much on the social media about Mengen. Observations exhibited that the population living in the Şarköy region has a much more intense social media sharing culture. It is possible to see that people from Şarköy are able to carry on their fellow-townsmenship relationships through social media much more intensively than people from Mengen. The main reason for this was observed to be due to different customs and traditions. It was also seen that the adaptation to innovations is easier for those living in the Thrace region. Both social media sharing and one-to-one interviews reveal that people living in the Mengen area are more reluctant to share in social media. It is seen that especially people living in the Mengen region are more reluctant in social media usage and the number of shares in the Mengen social media account is much less than the number of shares in the Şarköy social media account.

\section{Results and Recommendations}

Within the scope of this study, it was investigated whether social media is effective in the fellow-townsmenship relationships of the people from Şarköy and Mengen districts and the people originally from these districts but living in the metropolitan areas. It is seen that cultural differences are reflected in this research because the two regions are very different from each other. It is seen that social media will be more active in the lives of people in the future. Observations reveal that people will actively use social media to maintain their cultural ties. It is foreseen that the second, third generation relatives and their fellow townsmen will actively communicate on social media. It is possible to indicate that the current situation is an adaptation process and that in the future, the younger generation will more actively reflect their fellowtownsmenship relationships in their social media accounts.

It is seen that active use of social media is important for the continuation of the concept of fellow-townsmenship, which forms the basis of the Turkish common culture and values. Social media accounts actively managed by the district municipalities and current people invited from social media accounts in cooperation with the offices of district administrators will be important in people finding each other and communicating.

Social media was observed to have an important power in terms of shaping the Turkish social structure and mass communication. 


\section{REFERENCES}

Akdemir D. Ş. (2017). “İnsan Haklarının Korunmasında Kent Konseylerinin Rolü: Eskişehir Örneği Üzerine Bir Değerlendirme”. Kent Akademisi, Kent Kültürü ve Yönetimi Hakemli Elektronik Dergi 10/3 (2017) 286-305.

Akgiş Ö. \& Karakaş E. (2018). "Bir Sosyal Ăg Olan Hemşehri Derneklerinin Yoksullukla Mücadeledeki Rolü Üzerine Uygulamalı Bir Araştırma”. Ege Coğrafya Dergisi 27/1 (2018) 21-34.

Akoğlan Kozak M. \& Kızılırmak İ. (2006). "Turistik Ürün Çeşitlendirmesi Kültür ve Turizm Müdürleri Görüşlerine Dayalı Bölgesel Yaklaşımlar”. Mustafa Kemal Üniversitesi Sosyal Bilimler Enstitüsü Dergisi 3/5 (2006) 1-24.

Aktaş E. - Aka A. \& Demir M. C. (2006). "Kinship (Hemşehri) Associations and Rural Transformation in Turkey". Munich Personal RePEc Archive 12 (2006) 51-58.

Aktaş E. - Aka A. Ç. \& Demir M. C. (2012). “Türkiye'deki Hemşehri Derneklerinin Kırsal Yapıdaki Rolü”. Mülkiye Dergisi 36/3 (2012) 101-132.

Aktaş E. - Aka A. \& Demir M. C. (2006). “Türkiye'de Hemşehri Dernekleri ve Kırsal Dönüşüm”. Tarım Ekonomisi Dergisi 12/2 (2006) 51-58.

Altay N. \& Gümüş N. (2010). "Hemşehrilik ve İzmir'deki Hemşehri Dernekleri”. E-Journal of New World Sciences Academy 5/3 (2010) 231-239.

Arslan A. (2007). "Kalkınma Dinamikleri ve Sorunları Bakımından Kelkit Hafzasının Genel Bir Değerlendirmesi”. Karadeniz Araştırmaları Dergisi 12 (2007) 85-98.

Atar Ö. G. (2016). "Medya Okuryazarlığının Dönüşümünün Gerekliliği”. Asos Journal (2016) 349-359.

Bateman T. S. \& Organ D. W. (1983). "Job Satisfaction and the Good Soldier: The Relationship Between Affect and Employee "Citizenship"'. Academy of Management Journal 26/4 (1983) 587-595.

Bekiroğlu O. \& Balcı Ş. (2016). "Kültürlerarası İletişim Duyarlılığının İzlerini Aramak: İletişim Fakültesi Öğrencileri Örneğinde Bir Araştırma”. Türkiyat Araştırmaları Dergisi 35 (2016) 429-460.

Beyhan B. (2011). "Toplumsal Bilişsel Yakınlık ve İşgücü Hareketliliği: Hemşehrilik Bağları Üzerinden Bir İrdeleme”. Anadolu Üniversitesi Sosyal Bilimler Dergisi 11/3 (2011) 199-238.

Blanchard O. (2012). Social Media ROI Managing and Measuring Social Media Efforts in Your Organization. London 2012.

Bourdieu P. (1986). The Forms of Capital Handbook of theory and Research for The Sociology of Education. New York 1986.

Carlson T. \& Djupsund, G. (2014). "Taking Risks in Social Media Campaigning: The Early Adoption of Blogging by Candidates”. Scandinavian Political Studies 37/1 (2014) 21-40.

Çelik A. (2013). "Kent Yönetimi Bağlamında Kent Konseyinin İşlevleri Üzerine Bir Değerlendirme”. C.Ü. Iktisadi ve İdari Bilimler Dergisi 14/2 (2013) 215-229.

Dural A. B. \& Yaş, S. (2007). "Göç Eden Nüfusta Grup Içi Tabakalaşma ve Siyasetin Yeniden Şekillenmesi”. Akademik Fener (2007) 22-31.

Erkal H. \& Şentürk, B. (2015). “Örgüt Kuramı Yazını Kapsamını Yeniden Düşünmek: Türkiye'de Hemşehrilik ve Hemşehri Dernekleri”. Akademik Baklş Dergisi 50 (2015) 339-353.

Fliche B. (2005) "The Hemşehrilik and the Village: The Stakes of an Association of Former Villagers in Ankara”. European Journal of Turkish Studies, 2. http://ejts.revues.org/385 [Erişim Tarihi 08.10.2012].

Göngör N. (2006). "Göç Olgusu ve Arabesk”. 8-11 Aralık Uluslararası Göç Sempozyumu (Haziran 2006). İstanbul.

Guida M. (2013). "Friendship, kingship and interest: Informal politics in Turkey and the Example of Vote Mobilization in Istanbul and Şanlıurfa". Alternatatives Journal 12/4 (2013) 65-76.

Güven E. \& Demir E. (2014). "The relationship between classroom community feeling and "hemsehrilik" attitude levels of teacher candidates". Procedia - Social and Behavioral Sciences 116 (2014) 3208-3212.

Israel S. (2009). Twitterville How Businesses Can Thrive in the New Global Neigborhoods. New York 2009.

Harvey David. (2014). Post Modernliğin Durumu. İstanbul 2014.

Harvey David. (2016). Kent Deneyimi. İstanbul 2016.

Hewitt H. (2005). Blog Understanding the Information Reformation That's Changing Your. Nashville 2005. Holston J. \& Appadural A. (1996). "Public Culture". 8 (1996) 187-204.

Horzumlu A. H. T. (2017). "Yörük Kültürünü Tanıtmak: Dernekleşme Faaliyetleri ve Yörük Şenlikleri”. Türkiyat Mecmuası 27/2 (2017) 239-255. 
Jiang J. - Wang C. \& Tian Y. (2018). "Urban Activity Summarization with Geo-Tagged Social Media Data". 4th International Conference on Computer and Technology Applications IEEE 2/18 (2018) 1619.

Kaçer M. (2017). “Türkiye’de Belediye Başkanlığı Seçimlerinde Yenilenme Oranı 1984 - 2014 ve Dönem Sinırlandırması". Doğu Anadolu Sosyal Bilimlerde Eğilimler Dergisi 1/1 (2017) 25-42.

Kanovsky M. A. \& Pugh S. D. (1994). "Citizenship Behavior and Social Exchange". Academy of Management Journal 37/3 (1994) 656-669.

Kılıç S. (2009). "Kamuoyu Oluşum Sürecinde Sosyal Hareketler ve Medya". Niğge Üniversitesi İ̈BF Dergisi 2/2 (2009) 150-167

Köse A. (2018). "Küreselleşme Çağında Bir Aidiyet Zemini Ve Örgütlenme Şekli Olarak Hemşehrilik". Akademik Incelemeler 3/1 (2018) 221-232.

Kurtoğlu A. (2001). Hemşehrilik ve Şehirde Siyaset. İstanbul 2001.

Kurtoğlu A. (2018). "Mekansal Bir Olgu Olarak Hemşehrilik ve Bir Hemşehrilik Mekanı Olarak Dernekler". European Journal of Social Studies. Kaynak: https://www.researchgate.net/publication/ 30453637

Kurtoğlu A. (2012). "Siyasal Örgütler ve Sivil Toplum Örgütleri Bağlamında Hemşehrilik ve Kollamacıllk". Ankara Üniversitesi SBF Dergisi 67/1 (2012) 141-169.

Tombul I. (2019). "Digital Media Consumption of Children in Cinema". Ed. Gülşah Sarı. Children's Consumption of Digital Media (2019) 177-194.

İzmirli Olmak Sempozyum Kitabl, 22-24 Ekim 2009, İBB Ahmet Pirifltina Kent Arşivi ve Müzesi, İzmir.

Marshall T.H. (1950). Citizenship and Social Class. Cambridge 1950.

Millward A. A. (2011). "Urbanisation viewed through a geostatistical lens applied to remote-sensing data". Area 43/1 (2011) 53-66

Mirza A. (2016). "Kenar Mahalleliğin Sinemadaki Yansımaları". Abant Kültürel Araşstırmalar Dergisi AKAR 1/2 (2016) 21-33.

Moorman R. H. (1991). "Relationship Between Organizational Justice and Organizational Citizenship Behaviors: Do Fairness Perceptions Influence Employee Citizenship?” Journal of Applied Psychology 76/6 (1991) 845-855.

Mossberger K. \& Tollbert, C. J.\& McNeal, R. S. (2008). Digital Citizenship. Cambirdge 2008.

Mouffe C. (1992). "Democratic Citizenship and the Political Community". The Mit. Press 61/102 (1992) 70-82.

Organ D. W. (1997). "Organizational Citizenship Behavior It's Construct Cleanup Time". Human Performance 10/2 (1997) 85-97.

Öksüz M. (2018). "Buralarda yabancı yok: Hemşehri derneklerinin kentlileşme üzerine etkisi, Ankara'daki Oflular örneği". Türk Coğrafya Dergisi 70 (2018) 87-98.

Öksüz Y. \& Öztürk M. B. (2017). "Relationship between Levels of Student Alienation and Hemsehrilik Attitudes of University Students: A Study on Kirgız-Turkish Manas University Students”. Universal Journal of Educational Research 5/7 (2017) 1182-1191.

Özbay F. (2014). "Türkiye Aile Yapısı Araştırması İleri Analiz Raporu Ankara". TC Aile ve Sosyal Politikalar Bakanlığl ve IPSOS (2014) 1-48.

Özdemir B. G. (2018). "Şimdiki Zaman: Kadın Karakterlerin Film Mekanlarındaki Temsilinin Feminist Film Eleştirisi Çerçevesinde İncelenmesi”. Sinecine 9/2 (2018) 131-164.

Özerkmen N. \& Kahya Y. (2008). “Organize Suç Örgütlerinin Oluşumunda Hemşehrilik İlişkilerinin Rolü”. Polis Bilimleri Dergisi 10/4 (2008) 15-42.

Potsakoff P. M., Mackenzie S. B. \& Moorman R. H. (1990). "Transformational Leader Behaviours And Their Effecets On Followers Trust in Leader". Satisfaction and Organizational Citizenship Behaviors, Leadership Quarterly 1/2 (1990) 107-142.

Romano Y. \& Penbecioğlu M. (2009). "From Poverty in Turns to New Poverty: A Scrutinize to Changing Dynamics of Urban Poverty in Turkey". Toplum ve Demokrasi 3/5 (2009) 135-150.

Sarı G. (2017). "Transmedya Hikaye Anlatıcıllı̆ı: Kötü Çocuk Örneği”. Abant Kültürel Çalışmalar Dergisi 2/4 (2017) 71-79.

Smith C. A., Organ D. W. \& Near J. P. (1983). "Organizational Citizenship Behavior: Its Nature and Antecedents". Journal of Applied Psychology 68/4 (1983) 653-663.

Taylor C. (1990), "Modes of Civil Society". Public Culture 3 (1990) 1.

Terzi E. \& Koçak Y. (2014). "Hemşehri Dernekleri, Hemşehrilik Bilinci ve Kentlileşme İlişkisi Üzerine Bir Araştırma: İstanbul/Sultangazi'deki Karslı Hemşehri Dernekleri Örneği’. Selçuk Üniversitesi Sosyal 
Bilimler Enstitüsü Dergisi 32 (2014) 137-150.

Topçuoğlu A. \& Eroğlu S. E. (2013). "Sosyal Sermayenin Akrabalık Hemşehrilik ve Güven İle İlişkisi: Konya Sanayi İşletmeleri Örneği”. HAK-IŞ̧ Uluslararası Emek ve Toplum Dergisi 2/3 (2013) 124-145.

Usta S. \& Bilgi E. (2017). "Hemşehrilik Bilinci ve Kent Konseyleri: Karaman İlinde Bir Araştırma". Süleyman Demirel Üniversitesi Sosyal Bilimler Enstitüsü Dergisi 1/26 (2013) 223-252.

Yağız A., Demirel A. S., Karabay D., Yalçın G., Egemen M. S. \& Utku Y. (2020, Ocak 14). Yerel Medyanın Dijital Teknolojilere Uyumu: Türkiye'deki Yerel Gazetelerin Dijital Medyayı Kullanımı Üzerine Bir İnceleme. Kaynak: http://www.academia.edu/9728266/. Erişim tarihi: 14 Ocak 2014.

Yakar M. \& Eteman F. S. (2017). "Türkiye'de İller Arası Göçlerin Nodexl İle Sosyal A ̆g Analizi”. Göç Dergisi 4/1 (2017) 82-109. 